\title{
Effect of Plant Population and Fertilization on Growth and Yield of Papaya \\ (Carica papaya L.) $)^{1,2}$
}

\author{
Guillermo Colom-Covas ${ }^{3}$
}

\begin{abstract}
A planting distance experiment with the Sunrise Solo papaya cultivar was performed in St. Augustine, Trinidad, West Indies, in which the distance between plants was varied from 0.602 to $3.046 \mathrm{~m}$. Each plant received a total of 340.2 g of 13-13-20 fertilizer in six bimonthly applications.

Plant height, stem diameter, and fruit yields during a 5-month harvesting period attained maximum values of $309 \mathrm{~cm}, 30 \mathrm{~cm}$, and $328.86 \mathrm{ql}^{4} / \mathrm{ha}$, respectively, at planting distances of $0.715,2.206$, and $0.987 \mathrm{~m}$. Petiole length did not vary significantly with variation in planting distance.

Fruit yield during the 5-month harvest period (August to December 1969) increased from $58.38 \mathrm{ql} / \mathrm{ha}$ with a planting distance of $0.602 \mathrm{~m}$ and $93.89 \mathrm{ql} /$ ha of 13-13-20 application to $328.86 \mathrm{ql} / \mathrm{ha}$ with a planting distance of $0.987 \mathrm{~m}$ and $34.87 \mathrm{ql} / \mathrm{ha}$ fertilization, decreasing to about $70 \mathrm{ql} / \mathrm{ha}$ as planting distance increased to $3.046 \mathrm{~m}$ and fertilization rate decreased to $3.66 \mathrm{ql} / \mathrm{ha}$.

A quartic algebraic equation fitted to the data explained $51 \%$ of the variation of fruit yield as a dependent variable on planting distance.
\end{abstract}

\section{INTRODUCTION}

Papaya is a delicious tropical fruit for which there is a good demand, both for fresh fruit and processing. The enzyme papain is extracted from its latex, and it is primarily grown for this purpose in some areas such as Ceylon, India, and some African countries. (5, 8, 9).

Due to the attacks of insects and diseases and to the relatively short period during which the ripe fruit keeps well, commercial papaya production for the fresh fruit market is a risky enterprise.

Studies of papaya diseases (4), pests (12), and the effects of seasonal variation upon flowering and sex expression of the Solo cultivar (2) have been carried out. Also, studies on adaptability of the Betty and Sunnybrook cultivars have been conducted in Florida and Australia $(1,3,8)$.

Planting distances varying from $1.83 \times 1.83 \mathrm{~m}$ to $4.57 \times 4.57 \mathrm{~m}$ have been used in different places $(1,2,6,9,10,11)$, but the influence of planting distance on fruit yield needs to be investigated more thor-

${ }^{1}$ Submitted to Editorial Board Sept. 5, 1974.

${ }^{2}$ This paper is based on work done to complete the requisites for the M.S. degree at the University of the West Indies, St. Augustine, Trinidad, West Indies (7).

${ }^{3}$ Deceased. Former Associate Horticulturist, Agricultural Experiment Station, University of Puerto Rico, Mayagüez Campus, Rio Piedros, P.R. Due to severe illness of the author, observations and fruit harvests from August to December 1969 were kindly taken care of by Miss Tessa Gardner-Brown.

${ }^{4}$ One $\mathrm{ql}=100 \mathrm{~kg}$. 
oughly since previous studies have not provided definite information in this respect. This paper presents the results of one such study in which plants set at different planting distances and receiving the same amount of fertilizer were compared.

\section{MATERIALS AND METHODS}

A planting distance experiment with papaya of the Sunrise Solo cultivar, in which each plant received the same quantity of fertilizer, was carried out in a field of the University of the West Indies, at St. Augustine, Trinidad, West Indies.

The experimental field was comprised of three cambered beds, each $152.4 \mathrm{~m}$ long and $12.2 \mathrm{~m}$ wide. The slope was southeast-northwest. The higher section of the field with the best drainage was chosen for the experimental site.

The results of the analyses of soil samples averaged as follows: $\mathrm{N}$, $0.09 \% ; \mathrm{P}_{2} \mathrm{O}_{5}, 4 \mathrm{p} / \mathrm{m}$; and exchangeable $\mathrm{K}, 0.11 \mathrm{meq} / 100 \mathrm{~g}$.

The Sunrise Solo cultivar, introduced from Hawaii where it was formerly known as HAES 63-22, produces pink-fleshed fruits with high total solid content, varying from $10^{\circ}$ to $14^{\circ}$ Brix.

The experimental design used was one of Nelder's systematic spacing designs (9). Each cambered bed was divided into five sections and each section included a series of concentric arcs with grid points representing the positions of the plants in each arc (fig. 1). The areas corresponding to the plants in an arc were equal and approximately rectangular, increasing from arc to arc as the radius of the arc increased. The areas allotted to the plants in the different ares varied from 0.362 to $9.281 \mathrm{~m}^{2}$ and distances between plants varied from 0.602 to $3.046 \mathrm{~m}$. Each arc included 11 plants. The two outside plants in each arc and the plants in the first and last arcs of each section were used as guard plants. Thus, measurements were made only on the inner nine plants of the inside arcs of each section.

The division of each cambered bed into five sections (A, B, C, D, E in every case) was necessary to locate all the treatments in each bed. There were 24 spacing-fertilizer treatments. Treatments 1 through 11 were tested in sections A, 11 through 16 in sections B, 16 through 19 in sections C, 20 through 22 in sections D, and treatments 23 and 24 in sections E.

Three seeds per bag were sown in black plastic bags in the greenhouse on November 11, 1968. The bags had been filled with a 3:3:1 mixture of River State loam top soil, rotted manure, and coconut fiber. A pink fungus growth which attacked the seedlings in the bags was controlled 


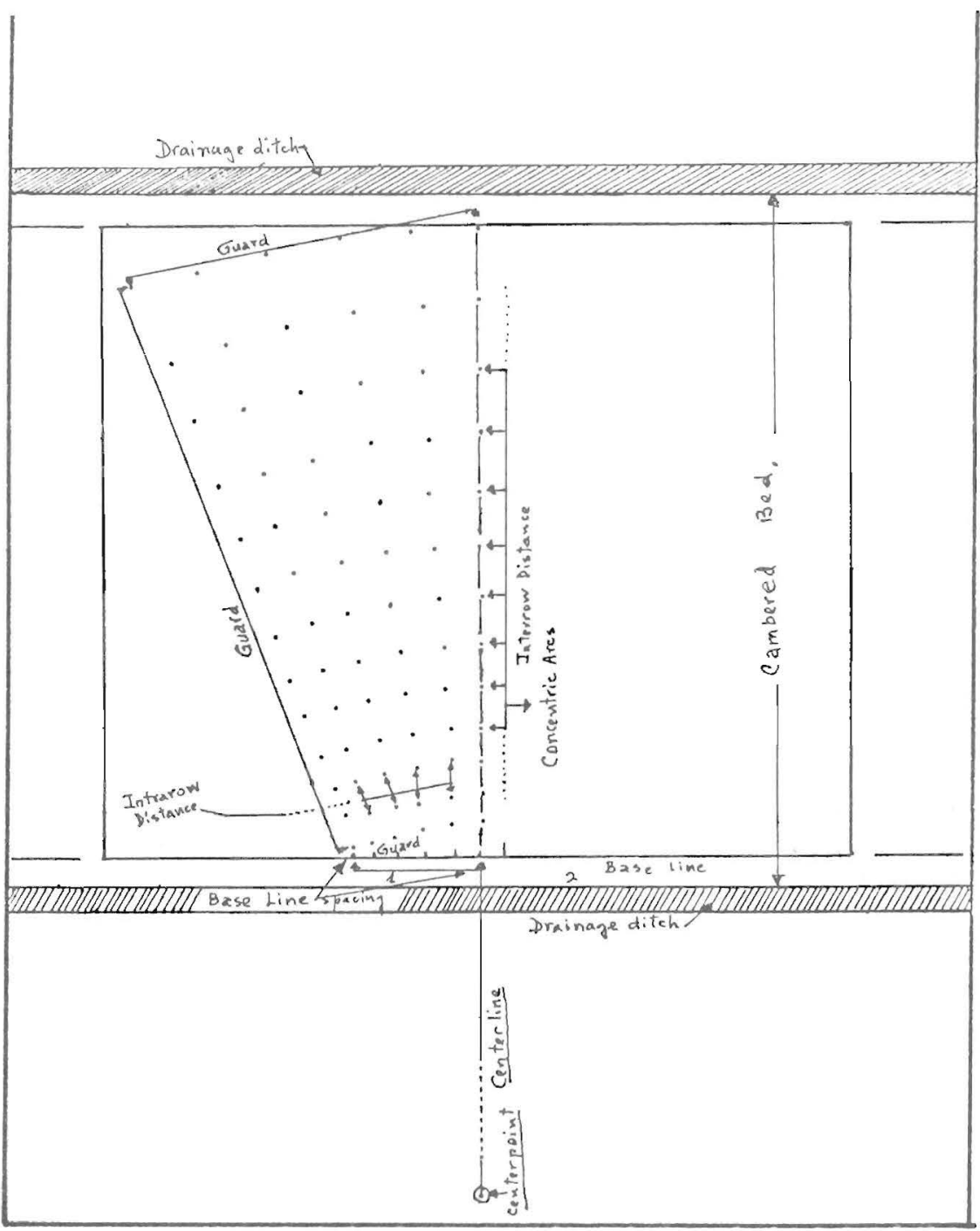

FIG. 1.-Fans in the Nelder systematic spacing design.

with a solution containing $3.75 \mathrm{~g}$ Perenox ${ }^{5}$ per liter of water. The slow growth of the plants in the bags was speeded up by adding to each bag

5 Trade names are used in this publication solely for the purpose of providing specific information. Mention of a trade name does not constitute a guarantee or warranty of equipment or materials by the Agricultural Experiment Station of the University of Puerto Rico or an endorsement over other equipment or materials not mentioned. 
1/2 cup of a solution containing 7.50 g of 13-13-20 fertilizer per liter of water and repeating the operation a week later.

On December 20 the seedlings were moved from the greenhouse and placed under $72 \%$ shade Saran netting. On December 30 the net was removed.

On January 11, 1969, the seedlings of one bag were planted in each corresponding field site. At planting time the plants in each site received $28.7 \mathrm{~g}$ of 13-13-20 fertilizer and their foliage was sprayed with a minor element solution containing $5 \mathrm{~g}$ of Mairol per liter of water. Each plant site also received $28.7 \mathrm{~g}$ of 13-13-20 on March 17 and on the 11th of May, July, September, and November 1969, for a total of $340.2 \mathrm{~g} / \mathrm{plant}$. The total fertilizer applications varied from $3.66 \mathrm{~kg} / \mathrm{ha}$ for plants of treatment 24 to $93.89 \mathrm{~kg} /$ ha for plants of treatment 1 (table 1).

Plant height to the apex, girth (stem diameter) at a height of $5.08 \mathrm{~cm}$, and petiole length of the lowest green leaf (from the stem to the base of the lamina) were measured on three randomly selected trees of each arc on January 22, February 5, February 26, March 17, April 1, April 28, May 21, and June 16; and on one randomly selected tree on August 8, September 2, and in October 1969. Flowering counts were made on April 1 and April 10, 1969. On the latter date the extra plants at each site were removed, leaving only one plant per site.

The insect vectors of bunchy top Empoasca papayae O. and Empoasca dilitara De Long and Davidson and of papaya mosaic were simultaneously controlled by regular sprayings with DDT 50\% WP at the rate of $5.6 \mathrm{~g} / \mathrm{l}$ of water, applied every 15 days with a knapsack sprayer using a Teejet 11004 nozzle. Control started on December 11, 1968.

To control fruit rot and anthracnose, Dithane M-45 at the rate of $5.6 \mathrm{~g} /$ 1 of water was sprayed once a month for the first 3 months; then twice a month. After fruit setting, fungicide sprays were combined with insect control sprays.

The area was maintained weed free and the ditches clean. The weeds around the trees were either cut or weeded out by hand, leaving a clean circular area around each tree. The area between the treatments was mowed with a Gravely mower whenever it was possible, but at closer spacings weeding was done either with a machete or pulled by hand. All dried grass was incorporated later as mulch around the trees.

Harvesting began on August 7, 1969, and ended in January 1970. For the purpose of the experimental data, a closing date was set at the end of December 1969. Harvesting was set to follow the standards used for harvesting fresh fruit, that is, when a yellowish or pinkish color appeared on the fruit.

Records were kept of the fruits harvested from each treatment and the data were statistically analyzed to determine the joint influence on fruit 
yield of plant area and quantity of fertilizer applied. The statistical studies included: an analysis of variance assuming no differential effects of the cambered beds or their sections on yield, analyses of covariance where covariance factors were either number of dead plants or the distance of each arc from the northernmost spot of the experimental site or both criteria combined, and fitting of various algebraic equations to treatment and yield data.

By April 1, 74\% of the plants had flowered, and by April 10, 94\%.

The control of bunchy top and anthracnose was satisfactory. In general, fruits were clean without blemishes.

Mosaic control was not quite effective after harvest had commenced, probably due to the rainy season that had just started. It was also learned later that aphids other than Empoasca papayae O. are able to transmit the mosaic, especially the ones using legumes as host plants (13).

\section{RESULTS}

Table 1 indicates that: 1) plant height, as of October 1969, varied slightly between the 1.363 and $3.046 \mathrm{~m}$ planting distances, corresponding to fertilizer rates between 3.66 and $18.31 \mathrm{ql} / \mathrm{ha}$, increasing to a maximum of $309 \mathrm{~cm}$ when the planting distance was reduced to $0.715 \mathrm{~m}$ and the fertilizer rate was increased to $66.58 \mathrm{ql} / \mathrm{ha}$ and then decreasing somewhat with a still closer spacing and increase in rate of fertilization; 2) stem diameter on September 5 showed increases with spacing and rate of fertilization per hectare; 3 ) there were no noticeable changes in length of petiole with variations in spacing or fertilization rate; 4) fruit yields per hectare had maximum values with planting distances between 0.987 and $1.157 \mathrm{~m}$ and fertilization rates of 25.43 and $34.87 \mathrm{ql} / \mathrm{ha}$ decreasing as the spacing or rate of fertilization differed from these levels.

The analysis of variance of the 5-month yield data, assuming no differential effects of the cambered beds or their sections on yield, showed significant differences among treatment mean yields. Attempts to improve the precision of the statistical analysis by correcting through covariance analysis for dead plants, for arc position as defined by its distance from the northernmost point of the experimental site, or by combining both criteria were not successful.

The following algebraic equation of the fourth degree, which was fitted to the data, expresses the influence on the 5-month fruit yield of the distance between plants in the corresponding arc:

$$
Y=-80.777+2,510.92 X-2,119.29 X^{2}+713.02 X^{3}-84.49 X^{4} \text {. }
$$

In this equation $Y$ is the 5-month fruit yield in quintals per hectare and $X$ is the distance between plants in the arc in meters. The explana- 
TABLE 1. - Planting distance, quantity of fertilizer, plant height, stem diameter, petiole length, and fruit yield of papaya experiment ${ }^{1}$

\begin{tabular}{|c|c|c|c|c|c|c|c|c|}
\hline \multicolumn{4}{|c|}{ Treatment } & \multicolumn{5}{|c|}{ Criteria } \\
\hline \multirow{2}{*}{ Section } & \multirow{2}{*}{ No. } & \multirow{2}{*}{$\begin{array}{l}\text { Planting } \\
\text { distance }\end{array}$} & \multirow{2}{*}{$\begin{array}{l}\text { Fertil- } \\
\text { izer }\end{array}$} & \multirow{2}{*}{$\begin{array}{l}\text { Plant } \\
\text { height }\end{array}$} & \multirow{2}{*}{$\begin{array}{l}\text { Stem di- } \\
\text { ameter }\end{array}$} & \multirow{2}{*}{$\begin{array}{l}\text { Petiole } \\
\text { length }\end{array}$} & \multicolumn{2}{|c|}{ Fruit yield } \\
\hline & & & & & & & Actual & Calculated $^{2}$ \\
\hline & & $M$ & Ql/ha & $\mathrm{Cm}$ & $\mathrm{Cm}$ & $\mathrm{Cm}$ & Ql/ha & Ql/ha \\
\hline $\mathrm{A}$ & 1 & 0.602 & 93.89 & 268 & 16.5 & 52.0 & 58.38 & 80.00 \\
\hline $\mathrm{A}$ & 2 & .653 & 79.61 & 295 & 17.5 & 53.0 & 121.38 & 111.60 \\
\hline A & 3 & .715 & 66.58 & 309 & 18.0 & 60.0 & 138.79 & 142.58 \\
\hline $\mathrm{A}$ & 4 & .771 & 57.22 & 295 & 20.0 & 63.5 & 173.27 & 165.18 \\
\hline A & 5 & .840 & 48.18 & 289 & 20.0 & 59.0 & 200.95 & 186.64 \\
\hline A & 6 & .909 & 41.14 & 279 & 23.5 & 70.0 & 92.27 & 201.45 \\
\hline A & 7 & .987 & 34.87 & 260 & 21.5 & 61.5 & 328.86 & 211.39 \\
\hline A & 8 & 1.069 & 29.77 & 260 & 24.0 & 69.0 & 255.71 & 215.26 \\
\hline A & 9 & 1.157 & 25.43 & 271 & 25.0 & 66.5 & 309.12 & 213.33 \\
\hline $\mathrm{A}$ & 10 & 1.257 & 21.54 & 249 & 22.0 & 58.5 & 189.45 & 205.14 \\
\hline A & 11 & 1.363 & 18.31 & 232 & 22.0 & 55.0 & 90.73 & 191.33 \\
\hline B & 11 & 1.363 & 18.31 & 191 & 21.5 & 48.0 & 110.82 & 191.33 \\
\hline B & 12 & 1.458 & 15.99 & 205 & 23.0 & 52.5 & 99.45 & 176.09 \\
\hline B & 13 & 1.563 & 13.92 & 205 & 27.5 & 56.5 & 185.61 & 157.78 \\
\hline $\mathrm{B}$ & 14 & 1.678 & 12.08 & 222 & 26.0 & 65.0 & 176.83 & 137.34 \\
\hline B & 15 & 1.798 & 10.52 & 225 & 25.0 & 52.0 & 207.16 & 117.12 \\
\hline B & 16 & 1.928 & 9.15 & 214 & 27.0 & 66.0 & 78.64 & 98.16 \\
\hline $\mathrm{C}$ & 16 & 1.928 & 9.15 & 190 & 24.0 & 62.5 & 57.46 & 98.16 \\
\hline $\mathrm{C}$ & 17 & 2.060 & 8.01 & 197 & 28.5 & 62.5 & 104.77 & 82.91 \\
\hline $\mathrm{C}$ & 18 & 2,206 & 6.99 & 216 & 30.0 & 63.0 & 115.74 & 71.59 \\
\hline C & 19 & 2.361 & 6.10 & 210 & 27.5 & 61.0 & 75.75 & 65.67 \\
\hline $\mathrm{D}$ & 20 & 2.359 & 6.11 & 149 & 20.5 & 38.0 & 38.98 & 65.71 \\
\hline D & 21 & 2.536 & 5.29 & 221 & 22.5 & 46.0 & 56.02 & 64.80 \\
\hline $\mathrm{D}$ & 22 & 2.725 & 4.58 & 189 & 23.0 & 53.5 & 29.42 & 66.64 \\
\hline $\mathrm{E}$ & 23 & 2.726 & 4.58 & 190 & 29.0 & 64.0 & 73.78 & 66.65 \\
\hline $\mathrm{E}$ & 24 & 3.046 & 3.66 & 207 & 30.0 & 65.0 & 69.70 & 55.21 \\
\hline
\end{tabular}

${ }^{1}$ Plant height to the apex measured in October 1969; stem diameter at a $5.08-\mathrm{cm}$ distance above ground level measured on Sept. 5, 1969; petiole length from stem to base of lamina of oldest green leaf measured in October 1969; fruit yield during 5-month harvest period, Aug. 7 to Dec. 31, 1969.

${ }^{2}$ Yields calculated with the equation: $Y=-80.777+2510.92 X-2119.29 X^{2}+713.02$ $X^{3}-84.49 X^{4}$, in which $X$ is the planting distance in meters and $Y$ is the yield in quintals per hectare.

tion of the variation of the fruit yield by the distance between the plants in the arc is significant at the 0.01 level with a coefficient of determination of 0.51 .

Table 1 and figure 2 show that the maximum yield estimated by this equation was about $215 \mathrm{ql} / \mathrm{ha}$ with a distance between plants of $1.069 \mathrm{~m}$, when approximately $30 \mathrm{ql} / \mathrm{ha}$ of 13-13-20 fertilizer were applied. 


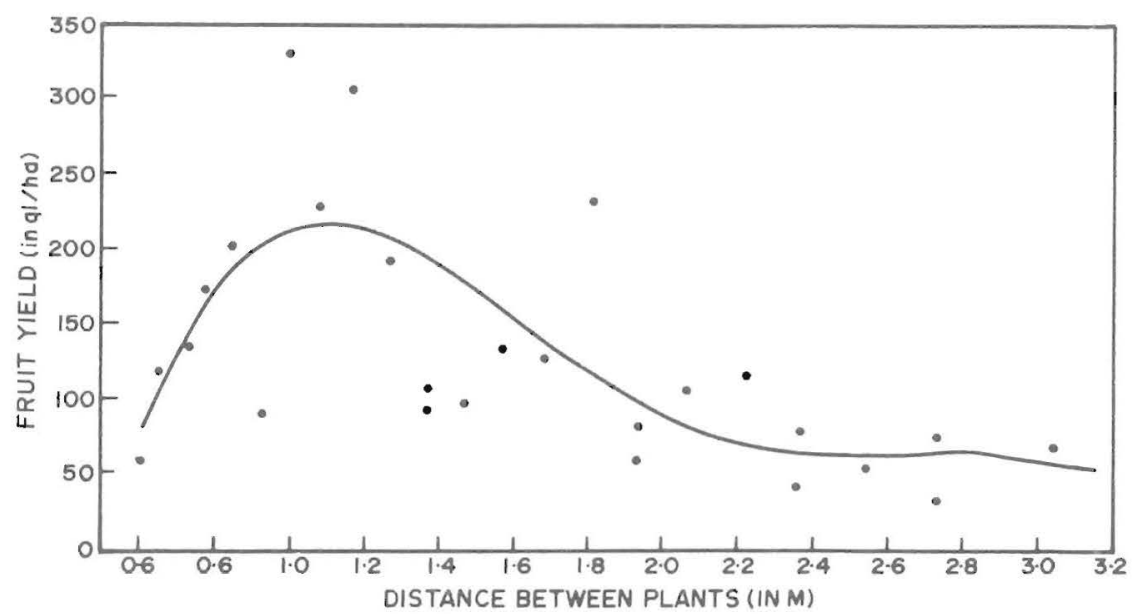

Fig. 2. - Influence of spacing between plants on fruit yield of Sunrise Solo papaya cultivar. Each plant received $340.2 \mathrm{~g}$ of $13-13-20$ fertilizer.

\section{RESUMEN}

Un estudio del efecto de la densidad de plantación sobre el desarrollo, tanto de las plantas como del fruto y el rendimiento del papayo, se realizó entre el 11 de noviembre de 1968 y el 31 de diciembre de 1969 en The University of the West Indies, St. Augustine, Trinidad.

El diseño experimental usado fue uno de los diseños sistemáticos de Nelder. La distancia entre plantas en los arcos correspondientes varió de 0.602 a $3.046 \mathrm{~m}$. Para el estudio se usó el cultivar Sunrise Solo. Como a cada planta se le aplicaron $340.2 \mathrm{~g}$. de un abono 13-13-20, la fertilización varió de 3.66 a 90.89 qm./ha.

La altura de las plantas, el diámetro del tallo y la longitud del pecíolo se midieron varias veces durante el período de crecimiento. La altura aumentó de $268 \mathrm{~cm}$. a $309 \mathrm{~cm}$. a medida que la distancia aumentó de 0.602 a $0.715 \mathrm{~m}$., pero disminuyó a cerca de $200 \mathrm{~cm}$. cuando la distancia aumentó hasta $1.363 \mathrm{~m}$.

El diámetro del tallo, tomado a una altura de $5.08 \mathrm{~cm}$. del suelo, aumentó de un mínimo de $16.5 \mathrm{~cm}$. en las plantas sembradas a $0.602 \mathrm{~m}$. de separación a un máximo de $30.0 \mathrm{~cm}$. en las sembradas entre 2.206 y $3.046 \mathrm{~m}$. de separación.

Ni la densidad de plantación ni la cantidad de abono afectaron la longitud del pecíolo.

Las frutas se cosecharon de agosto a diciembre de 1969. El rendimiento aumentó de $58.38 \mathrm{qm}$./ha. en plantas a $0.602 \mathrm{~m}$. y $93.89 \mathrm{qm}$. de abono por hectárea a $328.86 \mathrm{qm}$./ ha. en plantas a $0.987 \mathrm{~m}$. y abonadas con $34.78 \mathrm{qm}$./ha. El crecimiento mermó a alrededor de 70 $\mathrm{qm}$./ha. al aumentar la distancia a $3.046 \mathrm{~m}$. y disminuir la fertilización a $3.68 \mathrm{qm}$./ha.

Una ecuación cuártica aplicada a los datos experimentales explicó el 51 por 100 de la variación en rendimiento como variable dependiente de la densidad de plantación.

\section{LITERATURE CITED}

1. Agnew, G. W. J., Papaw culture in Queensland, Queensl. Agr. J. 66: 208-26, 1948.

2. Awada, M., Relationship of minimum temperature and growth rate, Hawaii Agr. Exp. St. Tech. Bull. 38, 16 pp, 1958.

3. Barnes, H., and Gregory, J. H., Papaw, Queensl. Agr. J. 48: 480-94, 1937.

4. Bird, J., and Adsuar, J., Viral nature of papaya bunchy top, J. Agr. Univ. P.R. 36(1): 5-11, 1952 . 
5. Cheema, G. S., and Dani, P. G., Papaya cultivation in the Bombay Presidency. Bombay Agr. Dept., Bull. 162, 1930.

6. Chenery, E. M., The soils of central Trinidad, Government Printer, Trinidad, 1952.

7. Colom-Covas, G., A study of population density in papaya (Carica papaya L.), Master's Thesis, Univ. West Indies, St. Augustine, Trinidad, West Indies, 1972.

8. Kerby, R. G., Papaw cultivation, Agr. Gaz. N.S. Wales 17(17): 169-70, 1960.

9. Lange, A. H., Factors affecting sex changes in the flowers of Carica papaya L. Proc. Amer. Soc. Hort. Sci. 77: 252-64, 1961.

10. Malan, E. F., Papaws in South Africa, Dep. Agr. S. Africa, Bull. 375, 1964.

11. Mloegorde, W., Papaw (Carica papaya, L.) Trop. Agr. (Ceylon), 1922.

12. Nelder, J. A., New kinds of systematic design for spacing experiments, Biometrics 18: 283-307, 1962

13. Shaeffers, G. A., Aphid vectors of the papaya viruses in Puerto Rico, J. Agr. Univ. P.R. 53(1): 1-73, 1969. 